\title{
Pengembangan Buku Panduan Penggunaan Aplikasi Resertifikasi Kompetensi untuk Karyawan Perhimpunan Dokter Sepsialis Penyakit Dalam Seluruh Indonesia
}

\author{
Puguh Septiadi Nugroho, ${ }^{\circledR}$ Hirmana Wargahadibrata $^{2}$, Erry Utomo ${ }^{2}$ \\ puguhseptiadinugroho@gmail.com \\ ${ }^{1}$ Universitas Negeri Jakarta, Jakarta, Indonesia. \\ ${ }^{2}$ Universitas Negeri Jakarta, Jakarta, Indonesia. \\ 3 Universitas Negeri Jakarta, Jakarta, Indonesia. \\ DOI: https://doi.org/10.21009/JPI.022.03
}

\begin{tabular}{l} 
Article History \\
\hline Received : 2019 \\
Accepted : 2019 \\
Published : 2019 \\
\hline
\end{tabular}

\section{Keywords}

$\overline{\text { Buku Panduan, Model }}$ ADDIE,

Pengembangan, SIUP, TDP.

\begin{abstract}
Abstrak
Penelitian pengembangan ini bertujuan untuk menghasilkan media cetak berupa buku panduan penggunaan Aplikasi Resertifikasi Kompetensi KIPD. Sasaran pengguna panduan ini ialah karyawan PAPDI cabang seluruh Indonesia. Penelitian pengembangan ini dilakukan berdasarkan model Rowntree yang memiliki tiga tahapan besar yakni tahap perencanaan, tahap persiapan penulisan, serta tahap penulisan dan penyuntingan. Evaluasi pada penelitian pengembangan ini dilakukan melalui expert review dan one-to-one evaluation. Evaluasi tersebut melibatkan 1 orang ahli materi, 1 orang ahli media, dan 5 orang pengguna. Nilai rata-rata yang diperoleh dari tahap expert review oleh ahli materi ialah 3,46 dan menunjukkan kategori sangat baik. Nilai rata-rata yang diperoleh dari tahap expert review oleh ahli media ialah 2,56 dan menunjukkan kategori baik. Pada tahap one-to-one evaluation, diperoleh nilai ratarata 3,4 yang menandakan secara keseluruhan panduan ini sangat baik dan dapat digunakan untuk memandu karyawan PAPDI cabang dalam menggunakan aplikasi Resertifikasi Kompetensi dengan benar dan tepat.
\end{abstract}

\section{Abstract}

This development research aims to produce a print media in the form of a guidebook to use of the Application "Resertifikasi Kompetensi KIPD”. This guidelines is meant to be used by employees Branch of PAPDI in Indonesia. This development research is referring to Rowntree's model that consists of three major stages; planning; preparation of writing; writing and editing. The evaluation on this development research was conducted through expert review and one-to-one evaluation. The evaluation involving one subject matter expert, one media expert, and five users. The average value obtainded from the expert review by the subject matter expert was 3,46 overall excellent. The average value obtainded from the expert review by the media expert was 2,56 overall good. In one-toone evaluation, obtained the average score 3,4 which signifies the overall guidance is excellent and can be used to guide the employees Branch of PAPDI to using the Application "Resertifikasi Kompetensi KIPD" correctly and precisely.

\footnotetext{
$\triangle$ Corresponding author : Puguh Septiadi Nugroho Adress: Universitas Negeri Jakarta 


\section{PENDAHULUAN}

Ilmu dan teknologi terutama teknologi informasi berkembang sangat pesat. Pesatnya perkembangan teknologi ini berdampak pada perubahan sosial budaya. Sistem dalam jaringan (online) marak di aplikasikan untuk beberapa kebutuhan di berbagai bidang. Misalnya ecommerce merupakan perubahan radikal dalam aspek ekonomi, di sektor pemerintahan ada e-government. Demikian pula di sektor pendidikan sudah berkembang e-Learning. Bidang pelayanan juga sudah banyak yang menggunakan sistem online. Salah satu faktornya untuk mengurangi jumlah berkas yang harus diarsipkan dalam bentuk fisik, karena semua berkas sudah terarsip dengan baik di jaringan internet.

Hal tersebut juga menjadi faktor diterapkannya sistem online oleh Kolegium Ilmu Penyakit Dalam Indonesia. Menurut Peraturan Konsil Kedokteran Indonesia Nomor 7 Tahun 2012, kolegium adalah badan yang dibentuk oleh organisasi profesi untuk masingmasing cabang disiplin ilmu di bidang kedokteran dan kedokteran gigi yang bertugas mengampu cabang disiplin ilmu tersebut. Secara umum, Kolegium Ilmu Penyakit Dalam bertugas mengampu segala kebutuhan cabang dari disiplin Ilmu Penyakit Dalam.

Ada beberapa stakeholder yang saling berkaitan di cabang Kedokteran Ilmu Penyakit Dalam, yaitu Perhimpunan Dokter Spesialis Penyakit Dalam Indonesia (PAPDI) pusat, Perhimpunan Dokter Spesialis Penyakit Dalam Indonesia (PAPDI) cabang, Kolegium Ilmu Penyakit Dalam (KIPD), Fakultas Kedokteran yang memiliki Program Studi Spesialis Ilmu Penyakit Dalam dan Fakultas Kedokteran yang memiliki Program Studi Subspesialis Ilmu Penyakit Dalam.

KIPD memiliki hubungan dengan PAPDI Cabang, dikarenakan salah satu fungsi dari KIPD adalah menerbitkan sertifikat kompetensi bagi anggota cabang (dokter yang telah menyelesaikan studi nya di FK spesialis Ilmu Penyakit Dalam). Dalam pendidikan Kedokteran spesialis selain mendapatkan ijazah dari Universitas, dokter yang telah menyelesaikan studi spesialis juga mendapatkan sertifikat kompetensi yang digunakan untuk menerbitkan Surat Tanda Registrasi. Surat Tanda Registrasi (STR) merupakan bukti tertulis yang diberikan oleh pemerintah kepada tenaga kesehatan yang telah memiliki sertifikat kompetensi. Sedangkan STR merupakan syarat utama agar dokter mendapatkan Surat Izin Praktek (SIP). Maka dari itu, fungsi KIPD menerbitkan sertifikat kompetensi sangat vital perannya dan sertifikat kompetensi tersebut memiliki masa berlaku selama 5 tahun.

Sejalan dengan makin berkembang pesatnya teknologi dan internet, maka proses perpanjangan sertifikat kompetensi dilakukan secara online menggunakan aplikasi website yang dibuat Kolegium Ilmu Penyakit Dalam (KIPD). Proses menggunakan aplikasi website ini sudah dilakukan oleh Sekretariat KIPD sejak 2014 namun berkas persyaratannya masih harus diserahkan oleh PAPDI Cabang berupa bentuk fisik (hardcopy) yang dikirimkan ke alamat KIPD. Per oktober 2018 KIPD menerapkan proses perpanjangan sertifikat kompetensi secara online, dimana PAPDI cabang yang anggota nya ingin melakukan perpanjangan setifikat kompetensi dapat mengajukan permohonan dengan mengunggah berkas di aplikasi website KIPD.

Namun dalam proses sosialisasi penerapan sistem online ini terdapat hal yang perlu dipertimbangkan, salah satunya yaitu SDM dari PAPDI Cabang yang akan mengimplementasikan sistem ini. Seperti yang diketahui, ada 38 PAPDI cabang yang tersebar di seluruh Indonesia dan memiliki SDM yang berbeda-beda. SDM dalam sebuah organisasi/perusahaan merupakan sumber daya paling vital serta aktivitas sentral dan strategis (Kaswan, 2012, h.1).

Dengan adanya penerapan sistem online ini maka perlu adanya peran memfasilitasi dari KIPD, berkaca dengan beragamnya SDM yang tersebar menjadi karyawan/sekretariat di PAPDI cabang. Memfasilitasi merupakan kata yang paling tepat karena maknanya adalah membantu seseorang untuk dapat mencapai tujuannya. Dalam hal ini adalah memfasilitasi belajar karyawan. Kata belajar digunakan karena karyawan baru perlu untuk belajar mengenai sistem online proses pengajuan perpanjangan sertifikat kompetensi bagi anggota nya tersebut. Karena apabila SDM ini tidak melaksanakan dan memahami tugasnya dengan baik, akan berakibat pada tidak terbitnya sertifikat kompetensi anggotanya 
yang akan berujung pada tidak terbitnya Surat Izin Praktek dari dokter yang bersangkutan.

Suatu hal baru yang akan diterapkan apabila tidak didampingi dengan hal yang memfasilitasi akan menimbulkan kesalahan dan masalah. Masalah yang muncul tersebut berkaitan dengan upaya memfasilitasi belajar karyawan, karena memfasilitasi belajar berarti memberikan sarana dan menghantarkan seseorang untuk mau belajar, bagaimana pun caranya. Ketika karyawan belajar maka akan meminimalisir masalah yang terjadi.

Memfasilitasi belajar menjadi salah satu tujuan penting Teknologi Pendidikan, hal ini terkandung dalam definisi Teknologi Pendidikan menurut Association for Educational Communication and Technology (AECT) pada tahun 2004, yaitu:

Educational technology is the study and ethical practice of facilitating learning and improving performance by creating, using and managing appropriate technological processes and resources.

Teknologi Pendidikan memiliki dua tujuan utama yaitu memfasilitasi belajar dan meningkatkan kinerja dengan memperhatikan efektivitas dan efisiensi dari intervensi yang dihasilkan. Memfasilitasi belajar memiliki berbagai cara, salah satunya adalah penggunaan job aids. Job aids atau alat bantu kerja dapat digunakan dalam hal efektivitas dan efisiensi pekerjaan. Job aids sebagai alat bantu merupakan penunjang untuk terjadinya belajar, selain itu merupakan pendukung untuk tercapainya suatu tujuan. Penggunaan job aids dirasakan lebih praktis dan relatif murah, namun perlu diperhatikan karakteristik kebutuhan yang cocok untuk digunakan.

Berdasarkan hal tersebut, peneliti bermaksud untuk menghasilkan sebuah buku panduan untuk memfasilitasi karyawan PAPDI Cabang dalam menerapkan sistem online ini. Penelitian pengembangan ini diharapkan mampu membuat karyawan belajar sehingga dapat mengimplementasikan sistem online dalam proses pengajuan perpanjangan sertifikat kompetensi dengan baik. Pemilihan pengembangan buku panduan juga didasarkan pada tujuan dari cara penyampaian informasi kepada karyawan tentang sistem online dalam proses pengajuan perpanjangan sertifikat kompetensi ini. Oleh karena itu pengembangan buku panduan penggunaan aplikasi resertifikasi kompetensi kolegium ilmu penyakit dalam diharapkan mampu membuat karyawan PAPDI cabang belajar dan memaksimalkan penerapan sistem online pengajuan perpanjangan sertifikat kompetensi ini.

Artikel ini menguraikan proses, pengembangan buku panduan penggunaan aplikasi Resertifikasi Kompetensi KIPD. Pengembangan ini diharapkan dapat berguna secara teoritis karena menjelaskan proses pengembangan buku panduan penggunaan aplikasi Resertifikasi Kompetensi KIPD, serta dapat pula dijadikan sebuah referensi bagi pengembang serupa lain dikemudian hari agar pengembangan dapat terlaksana lebih mendalam dan baik, selain itu hasil produk berupa buku panduan dapat digunakan bagi karyawan PAPDI cabang untuk membantu menggunakan aplikasi resertifikasi kompetensi KIPD dengan benar dan tepat, serta untuk Dokter Spesialis Penyakit Dalam (internist) dapat memperlancar proses penerbitan sertifikat kompetensinya.

\section{METODE}

Pendekatan penelitian ini menggunakan metode penelitian pengembangan (development research). Penelitian pengembangan adalah metode penelitian yang digunakan untuk menghasilkan produk tertentu dan menguji keefektifan produk tersebut (Sugiyono, 2011). Model penelitian pengembangan yang akan digunakan dalam penelitian ini adalah model Rowntree. Model ini memiliki 3 tahapan utama yang sistematis mulai dari tahap perencanaan, tahap persiapan penulisan, dan tahap penulisan dan penyuntingan.

Pada penelitian buku panduan penggunaan aplikasi Resertifikasi Kompetensi KIPD untuk karyawan PAPDI cabang seluruh Indonesia, bila dijabarkan alur penggunaan modelnya sebagai berikut: 
Tahap perencanaan bertujuan untuk mendapatkan beberapa hal antara lain, karakteristik pengguna bahan ajar diperoleh melalui sebuah wawancara yang menghasilkan data usia, latar belakang pendidikan, kemampuan awal, motivasi kerja, dan sumber belajar yang tersedia. Data-data tersebut menjadi studi pendahuluan dalam perumusan tujuan umum dan khusus, penyusunan garis besar isi, penentuan media, pendukung belajar serta pertimbangan bahan ajar yang telah ada.

Selanjunya tahap persiapan penulisan bertujuan untuk mendapatkan beberapa hal antara lain, sumber-sumber yang tersedia dan hambatannya, pengurutan ide dan gagasan, pengembangan aktivitas dan umpan balik, penentuan contoh-contoh terkait, penggunaan grafis, penentuan peralatan yang dibutuhkan, hingga rumusan bentuk fisik.

Tahap terakhir ialah tahap penulisan dan penyuntingan yang merupakan penuangan dari semua ide dan gagasan di tahapan-tahapan sebelumnya. Dalam tahap ini terdapat beberapa hal yang didapatkan antara lain draft berdasarkan garis besar isi materi yang telah dibuat, ilustrasi dan foto yang sesuai, assesmen belajar serta uji coba dan masukan perbaikan.

Pengembangan buku panduan penggunaan aplikasi Resertifikasi Kompetensi KIPD ini melibatkan satu orang pengkaji materi, satu orang pengkaji media dan lima orang pengguna. Teknik evaluasi yang digunakan ialah expert review dan one-to-one tryouts. Pada tahap evaluasi, digunakan kuesioner sebagai instrumen penelitian. Kuesioner yang dibuat menggunakan skala 1-4 untuk menilai aspek-aspek sebagai berikut: 1) materi/konten, 2) karakteristik panduan, 3) visual, 4) verbal, 5) tipografi, 6) fisik buku. Untuk mengolah data yang diperoleh melalui kuesioner, digunakan teknik analisis data menggunakan rumus statistik sederhana untuk mengetahui skor rata-rata yang selanjutnya dianalisis secara deskriptif untuk mengambil kesimpulan.

\section{HASIL DAN PEMBAHASAN}

Pengembangan buku panduan penggunaan aplikasi Resertifikasi Kompetensi KIPD dengan menggunakan model Rowntree, hasil penjabaran pengembangannya sebagai berikut:

\section{A. Tahap Perencanaan}

Dalam tahapan ini terdapat beberapa hal yang dilakukan sebagai berikut:

a. Karakteristik Pengguna Bahan Ajar

Kegiatan awal ini bertujuan untuk menganalisis karakteristik pengguna serta media pembelajaran yang sesuai. Proses analisis dilakukan peneliti melalui wawancara dengan mengajukan beberapa pertanyaan via telepon yang ditujukan kepada 4 orang karyawan PAPDI cabang yang terbagi atas 4 wilayah yaitu Barat (PAPDI cabang Aceh), Tengah 1 (PAPDI cabang Surakarta), Tengah 2 (PAPDI Cabang Kalimantan Tengah), Timur (PAPDI Cabang NTB). Adapun hasil wawancara yang diperoleh, akan dijabarkan dalam bentuk sebuah tabel:

Tabel 1 Hasil Wawancara Tahap Analisis

\begin{tabular}{|l|l|}
\hline \multicolumn{1}{|c|}{ Faktor } & \multicolumn{1}{|c|}{ Deskripsi } \\
\hline Demografi & Karyawan PAPDI cabang \\
& memiliki rentang usia 24- \\
& 55 tahun (diambil dari \\
& data yang dimiliki oleh \\
& Kolegium IPD). \\
& - Terkait sistem online ini \\
& PAPDI cabang bagian \\
& Indonesia Timur \\
& terkendala karena sinyal \\
& didaerahnya belum stabil \\
& Karyawan PAPDI cabang \\
& $>40$ tahun masih \\
& terkendala dalam \\
& menggunakan aplikasi \\
& resertifikasi kompetensi \\
& Motivasi kerja karyawan \\
& PAPDI cabang terus ingin \\
& mengenal hal-hal baru \\
termasuk aplikasi & resertfikasi kompetensi \\
& KIPD \\
\hline Motivasi & Mengikuti dengan \\
& seksama arahan-arahan \\
& yang dilakukan sesama \\
& karyawan PAPDI dari \\
& cabang lainnya emukan \\
\hline
\end{tabular}


Puguh Septiadi Nugroho | JPI/Vol.o2/No.02/2019| H. 96-105

\begin{tabular}{|c|c|}
\hline & $\begin{array}{l}\text { pada saat berlangsungnya } \\
\text { proses pengurusan. }\end{array}$ \\
\hline Belajar & 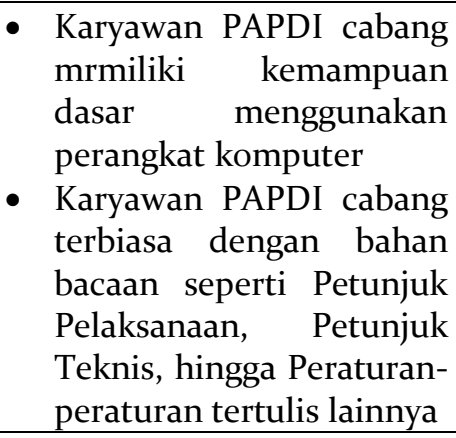 \\
\hline $\begin{array}{l}\text { Latar } \\
\text { Belakang } \\
\text { Studi }\end{array}$ & 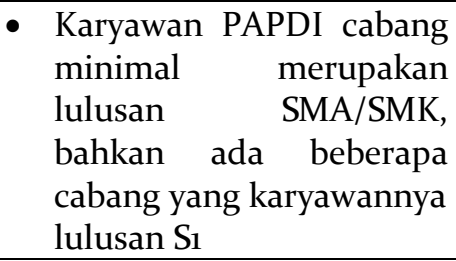 \\
\hline $\begin{array}{l}\text { Sumber } \\
\text { Belajar }\end{array}$ & 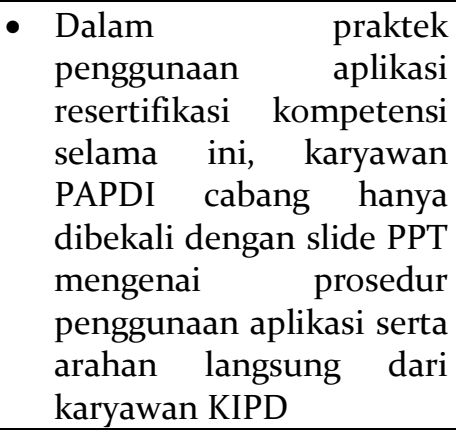 \\
\hline
\end{tabular}

Berdasarkan table 1, maka dapat dilihat bahwa bahwa karyawan PAPDI cabang membutuhkan sumber belajar yang khusus memuat prosedur penggunaan aplikasi resertifikasi kompetensi KIPD. Penyebab munculnya kebutuhan tersebut dikarenakan pihak KIPD tidak memfasilitiasi para karyawan PAPDI cabang seperti tidak adanya buku panduan penggunaan aplikasi resertifikasi kompetensi. Hal ini akan menjadi buruk, ketika karyawan PAPDI cabang mengalami pergantian/peremajaan.

b. Merumuskan Tujuan Umum dan Khusus

Berdasarkan dari hasil analisis di awal, maka peneliti mengidentifikasi keterampilan apa yang harus dicapai terkait penggunaan aplikasi resertifikasi kompetensi KIPD oleh karyawan PAPDI cabang seluruh Indonesia. Dengan demikian peneliti merumuskan tujuan umum dan khusus sebagai berikut:

1. Tujuan Pembelajaran Umum
Setelah menggunakan buku panduan "penggunaan aplikasi resertifikasi kompetensi kolegium ilmu penyakit dalam", karyawan PAPDI Cabang mampu menggunakan aplikasi resertifikasi kompetensi KIPD dengan benar dan tepat

2. Tujuan Pembelajaran Khusus

a) Karyawan PAPDI Cabang dapat menjelaskan persyaratan anggota PAPDI dalam pengajuan resertifikasi kompetensi

b) Karyawan PAPDI Cabang dapat mengidentifikasi tools yang tersedia pada aplikasi KIPD beserta fungsinya

c) Karyawan PAPDI Cabang dapat mengaplikasikan tahapan pengajuan permohonan resertifikasi kompetensi anggota PAPDI secara kontinu

c. Menyusun Garis Besar Isi

Setelah merumuskan tujuan pembelajaran umum dan khusus, peneliti menyusun garis besar berdiskusi dengan ahli materi yaitu Ibu Kanu Eltantrie, SKM. Peneliti membuat draft mengenai isi materi yang akan dimuat dengan mengacu pada tujuan pembelajaran yang telah dirumuskan serta mengolah materi dari aplikasi resertifikasi kompetensi KIPD

Dari hasil diskusi didapatkan sebuah GBIM yang terlampir, guna selanjutnya menjadi materi yang akan dimuat dalam buku panduan penggunaan aplikasi resertifikasi kompetensi untuk karyawan PAPDI cabang seluruh Indonesia, dengan pokok bahasan sebagai berikut:

- Pokok bahasan $1 . \quad$ Seputar

Kolegium Ilmu Penyakit Dalam dan ranah $\mathrm{P}_{2} \mathrm{~KB}$ di Kedokteran Spesialis Penyakit Dalam

- Pokok bahasan 2. Aplikasi resertifikasi kompetensi KIPD

- Pokok bahasan $3 . \quad$ Tahapan permohonan pengajuan resertifikasi kompetensi 
d. Menentukan Media

Setelah menentukan pokok bahasan dari tujuan pembelajaran yang telah dirumuskan, maka peneliti berdiskusi dengan ahli materi. Dari hasil diskusi tersebut maka ditentukan media yang akan dikembangkan adalah buku panduan dalam bentuk cetak, dikarenakan menyesuaikan dengan analisis yang dilakukan diawal serta disesuaikan dengan produk yang selalu dihasilkan oleh Kolegium Ilmu Penyakit Dalam yaitu buku dalam bentuk cetak yang dapat digunakan secara menyeluruh oleh seluruh karyawan PAPDI cabang di Indonesia.

e. Merencanakan Pendukung Belajar

Dalam wawancara di tahap analisis, antar karyawan PAPDI cabang terbiasa saling berbagi, maka dari itu peneliti merencanakan pembuatan Group chat di Whats App yang berisikan semua karyawan PAPDI cabang dan dapat digunakan sebagai wadah diskusi dan berbagi masalah serta solusi dalam mendukung fungsi buku panduan penggunaan aplikasi resertifikasi kompetensi KIPD.

f. Mempertimbangkan Bahan Belajar yang Sudah Ada

Dalam mengembangkan buku panduan penggunaan aplikasi resertifikasi kompetensi KIPD ini peneliti mempertimbangkan bahan belajar yang sudah ada yaitu Buku Petunjuk Teknis P2KB Ilmu Penyakit Dalam, sebagai bagian yang akan dimunculkan di bagian awal buku panduan ini.

\section{B. Tahap Persiapan Penulisan}

a. Pada tahap pertama, peneliti berkoordinasi dengan rekan-rekan kerja di Kolegium Ilmu Penyakit Dalam saat mengunjungi karyawan PAPDI Cabang. Hambatan yang dihadapi oleh peneliti ialah keterbatasan waktu dan jarak, untuk menjaga proses pengembangan ini dapat selesai waktunya, maka peneliti berkoordinasi dengan rekan-rekan kerja untuk mengunjungi Kantor PAPDI cabang.
PAPDI cabang yang peneliti kunjungi yaitu cabang Bogor, Surakarta, Jawa Barat.

b. Pada tahap ini, peneliti mengkaji kembali hasil diskusi dengan ahli materi. Berdasarkan garis besar isi panduan yang telah ditetapkan, peneliti membuat urutan naskah buku panduan yang dikembangkan, serta mengurutkan tujuan pembelajaran yang ingin dicapai. Hasil dari tahap ini ialah Analisis Instruksional dan Naskah yang terlampir pada lampiran.

c. Pada tahap ini, setelah tersusun naskah yang telah dikaji oleh peneliti. Ahli materi memberikan masukan bahwa buku panduan ini harus lebih aplikatif. Produk ini bertujuan agar karyawan PAPDI cabang tidak hanya membaca, melainkan juga terbantu dalam menyelesaikan pekerjaannya dengan baik dan benar. Dengan demikian, diputuskan untuk membuat lembar kerja yang dapat diisi oleh pengguna. Lembar kerja tersebut berisi tabel isian guna mengecek kelengkapan berkas yang diajukan oleh dokter yang bersangkutan ketika mengurus proses resertifikasi kompetensi di PAPDI Cabang.

d. Berdasarkan masukan dari ahli materi, buku panduan tidak disarankan terlalu banyak ilustrasi, hanya diperlukan gambar penjelas materi yang tajam dikarenakan pengguna multikultural dan juga mengacu pada tujuan dikembangakannya buku panduan ini, sehingga materi tidak hanya disajikan dalam bentuk teks. Tata letak teks dan grafis yang digunakan juga disesuaikan dengan prinsip desain pesan agar tidak mengganggu aspek keterbacaannya.

e. Berikut rumusan bentuk fisik buku dan spesifikasi peralatan yang ditentukan

Bentuk fisik buku:

$\begin{array}{ll}\text { Ukuran buku } & : \mathrm{B}_{5} \\ \text { Kertas } & : \text { Cover (Art } \\ \text { Karton), Isi (Art Paper) } & \end{array}$




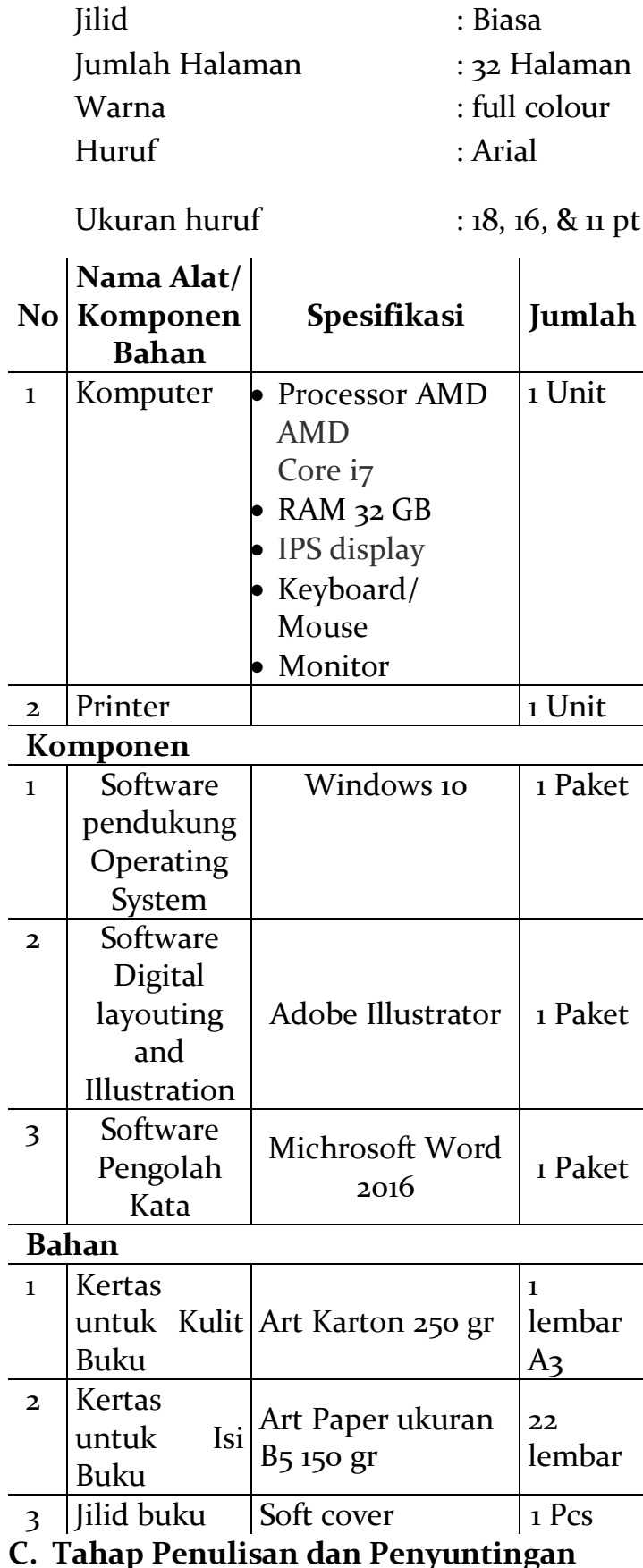

a. Peneliti membuat draf berdasarkan garis besar isi panduan dan naskah yang telah dirancang pada dua tahap sebelumnya. Selain itu, sistematika buku panduan ini juga mengalami beberapa kali revisi setelah mendapat saran pada tahap expert review, diantaranya mengganti desain cover, menghilangkan data-data pribadi yang muncul di buku panduan (seperti tanggal lahir, nomor handphone dan alamat), menghilangkan watermark logo dan menambahkan lembar kerja di halaman akhir buku panduan. Sistematika buku panduan penggunaan aplikasi resertifikasi kompetensi KIPD yang dikembangkan ialah sebagai berikut:

1) Cover depan

2) Daftar Isi

3) Kata Pengantar

4) Bab 1 : Pendahuluan

5) Bab 2 : Seputar Kolegium Ilmu Penyakit Dalam dan Ranah $\mathrm{P}_{2} \mathrm{~KB}$ di Kedokteran Spesialis Penyakit Dalam

a) Tugas dan Wewenang Kolegium dan Ilmu Penyakit Dalam

b) Penyelenggaraan Kegiatan $\mathrm{P}_{2} \mathrm{~KB}$ IPD

c) Resertifikasi Kompetensi

6) Bab $_{3}$ : Aplikasi Resertifikasi Kompetensi KIPD

a) Login

7) $\mathrm{Bab} 4$ : Tahapan Permohonan Pengajuan Resertifikasi Kompetensi

a) Mencari dan melengkapi database anggota

b) Melakukan proses pengajuan resertifikasi kompetensi Spesialis

c) Melakukan proses pengajuan resertifikasi kompetensi Sub Spesialis

d) Memantau proses penerbitan sertifikat kompetensi

e) Melihat dan mengunduh (download) sertifikat kompetensi

8) Bab 5 : Penutup

9) Lembar Kerja

b. Setelah menyelesaikan draf, pengembang memasukkan materi berupa teks, gambar dan ilustrasi yang telah dibuat sebelumnya, berdasarkan urutan dan tata letak yang telah 
dirancang. Proses melengkapi dan penyuntingan panduan ini dilakukan oleh pengembang berdasarkan masukkan dari ahli materi dan ahli media serta dibimbing oleh dosen pembimbing. Berikut merupakan contoh desain cover dan layout panduan mendesain konten e-learning:

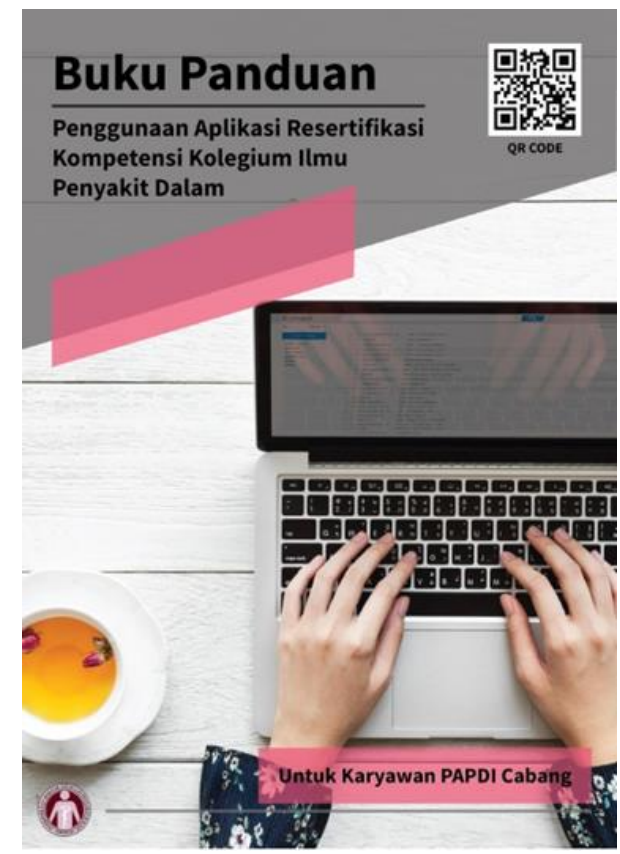

Gambar Cover Depan Buku Panduan

Kolegium IP $\theta$

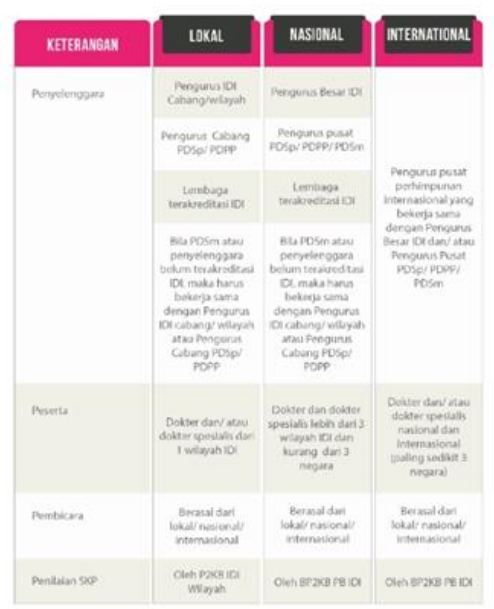

Gambar Layout Buku Panduan

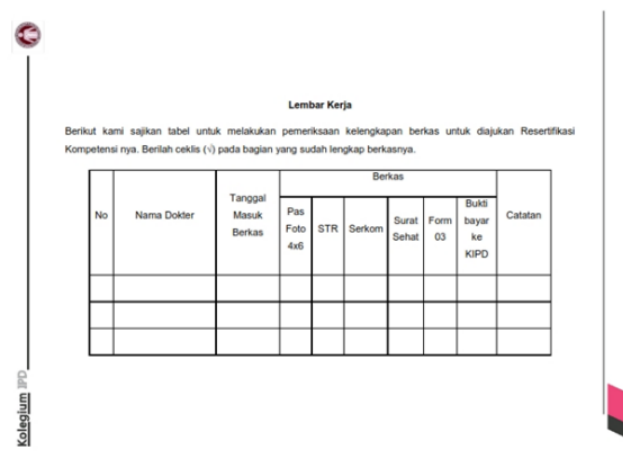

Gambar Lembar Kerja di Buku Panduan

c. Dalam pengembangan ini, pengembang melewati tahapan ini karena tidak menggunakan tes objektif untuk mengukur perubahan hasil belajar pengguna bahan ajar sebelum dan sesudah menggunakan bahan ajar yang dikembangkan, melainkan hanya melihat kemampuan pengguna dalam menggunakan aplikasi resertifikasi kompetensi KIPD berdasarkan tahapan yang disajikan buku panduan.

d. Ujicoba yang dilakukan oleh pengembang one-to-one tryouts. Pengembang menguji cobakan produk pada 5 orang Karyawan PAPDI Cabang yaitu Hendra Marlinta, Nanang Harri Nugroho, Januar Arifin, Heppy Poertopo, Herlina Ariyanti yang tersaji pada tabel rekapitulasi berikut:

Tabel Rekapitulasi Hasil One to One Tryouts

\begin{tabular}{lc}
\hline \multicolumn{1}{c}{ Responden } & Nilai Rata-Rata \\
\hline Hendra M. & 3.6 \\
Nanang Harri & 3.6 \\
Januar Arifin & 3.6 \\
Heppy Poertopo & 3.5 \\
Herlina A. & 3.1 \\
Rata-Rata & 3.4 \\
Keseluruhan & \\
\hline
\end{tabular}

Dari hasil one to one tryouts tersebut, didapatkan hasil nilai rata-rata sebesar 3.4. Maka hal ini menunjukan bahwa buku panduan dinilai sangat baik menurut sudut panduan karyawan PAPDI Cabang dan mampu 
memandu karyawan PAPDI cabang dalam menggunakan aplikasi resertifikasi kompetensi KIPD dengan benar dan tepat.

\section{SIMPULAN}

Produk hasil yang dikembangkan pada penelitian pengembangan ini adalah buku panduan penggunaan aplikasi resertifikasi kompetensi KIPD untuk karyawan PAPDI cabang seluruh Indonesia. Buku panduan ini dikembangkan berdasarkan analisis kebutuhan para karyawan PAPDI cabang, sehingga produk dapat dijadikan sebuah alternatif sumber belajar karyawan dalam menggunakan aplikasi resertifikasi kompetensi KIPD.

Pengembangan buku panduan ini dilakukan secara sistematis dengan mengacu pada model Rowntree, yang mencakup tiga tahapan besar, yaitu tahap perencanaan, tahap persiapan penulisan, dan tahap penulisan dan penyuntingan. Secara umum hasil penelitian ini ditujukan melalui tiga tahapan dalam model Rowntree sebagai berikut:

\section{Tahap Perencanaan}

Peneliti melakukan studi pendahuluan untuk menganalisis karakter calon pengguna buku panduan, serta melakukan diskusi dengan ahli materi dan ahli media dalam merumuskan tujuan dan merencanakan produk yang akan dikembangkan.

Hasil dari tahap ini tertuang dalam profil pengguna bahan ajar, rumusan tujuan umum dan khusus serta garis besar isi materi buku panduan.

\section{Tahap Persiapan Penulisan}

Peneliti mempertimbangkan hambatanhambatan yang dihadapi, membuat naskah, dan menentukan grafis pendukung penjelasan materi. Peneliti juga menentukan spesifikasi peralatan yang digunakan serta merumuskan bentuk fisik dari panduan yang akan digunakan.

3.Tahap Penulisan dan Penyuntingan

Pada tahap ini, seluruh draf yang telah diolah lalu disuntung dengan menyesuaikan tata letak teks maupun grafisnya, serta melakukan segala perbaikan berdasarkan masukan dari ahli serta pengguna.

Berdasarkan review yang telah dilakukan oleh peneliti dalam tahap uji coba dengan ahli materi, ahli media serta pengguna, maka dapat diperoleh kesimpulan sebagai berikut:

- Review ahli materi menyatakan bahwa Buku Pandan penggunaan aplikasi resertifikasi kompetensi KIPD secara umum bila ditinjau dari aspek materi dinilai sangat baik, dengan skor 3,46 dan layak untuk digunakan

- Review ahli media menyatakan bahwa

Buku Panduan penggunaan aplikasi resertifikasi kompetensi KIPD secara umum bila ditinjau dari aspek media dinilai baik dengan skor 2,56 dan layak digunakan dengan revisi sebelum melakukan one to one evaluation dengan pengguna

- One-to-one evaluation yang melibatkan 5 orang karyawan PAPDI cabang dari cabang Aceh, Surakarta, Bogor, Surabaya dan Jawa Barat menyatakan bahwa Buku Panduan penggunaan aplikasi resertifikasi kompetensi KIPD secara umum dinilai sangat baik dengan skor 3,4 dan layak untuk digunakan.

Dengan demikian, berdasarkan prosedur tahapan mengembangkan buku panduan serta uji coba yang telah dilakukan, maka dapat dinyatakan bahwa buku panduan penggunaan aplikasi resertifikasi kompetensi KIPD yang dikembangkan memiliki kualitas yang baik dan dapat digunakan untuk memfasilitasi karyawan PAPDI cabang di seluruh Indonesia untuk menggunakan aplikasi resertifikasi kompetensi KIPD sesuai dengan tahapannya.

\section{UCAPAN TERIMA KASIH}

Terimakasih saya ucapkan kepada Kolegium Ilmu Penyakit Dalam, dosen pembimbing, keluarga, para sahabat dan pihakpihak yang telah mendukung selama proses penelitian berlangsung.

\section{DAFTAR PUSTAKA}

Januszweski, Alan \& Molenda, Michael. (2010) Educational Technology: A Definition with Commentary, New York: Routledge, 
Puguh Septiadi Nugroho | JPI/Vol.o2/No.02/2019| H. 96-105

Prawiradilaga, Dewi S, Wawasan Teknologi Pendidikan, Jakarta: Kencana, 2012

Siswosoediro, Henry. Buku Pintar Pengurusan Perizinan \& Dokumen. Jakarta: Visimedia, 2008

Sugiyono. 2011. Metode Penelitian Kuantitatif Kualitatif dan RED. Bandung : Alfabeta.

http://www.kolegiumipd.org/ diakses 6 Agustus 2019 